\title{
Response of soil enzyme activities to synergistic effects of biosolids and plants in iron ore mine soils
}

\author{
E. N. Cele $^{1} \cdot$ M. Maboeta ${ }^{1}$
}

Received: 13 August 2015/Revised: 5 January 2016/Accepted: 25 June 2016/Published online: 7 July 2016

(C) Islamic Azad University (IAU) 2016

\begin{abstract}
Past mining activities in Swaziland have left a legacy of abandoned mine sites (iron ore, asbestos, diamond and coal mine dumps), all of which have not been reclaimed. These sites were recently (2013) considered by the country's wastewater treatment authorities as suitable places where biosolids can be applied, firstly as a biosolids disposal alternative and, secondly, as a strategy to accelerate mine soil remediation through phytostabilization. In order to understand the effects that this might have on mine soil conditions and microbiota, two (2) plant growth trials were conducted in biosolid-treated iron mine soils and one (1) trial on undisturbed soil, under greenhouse conditions, for twelve (12) weeks. According to the results obtained, the combination of biosolids and plants led to significant improvements $(p<0.05)$ in parameters related to soil fertility. Significant increases $(p<0.05)$ in alkaline phosphatase, $\beta$-glucosidase and urease soil enzyme activities were also observed. Copper and zinc were significantly $(p<0.05)$ increased $(\mathrm{Cu}$ from $17.00-50.13 \mathrm{mg} \mathrm{kg}^{-1}$; Zn from 7.59-96.03 $\mathrm{mg} \mathrm{kg}^{-1}$ ); however, these sludge-derived metals did not affect enzyme activities. Improvements in soil physicochemical conditions, organic matter-metal complexes, effects of plants on metals and the essentiality of $\mathrm{Cu}$ and $\mathrm{Zn}$ to soil enzymes were thought to have masked the effects of metals. Increases in soil enzyme activities were considered to be indicative of improvements in the quality, fertility health and self-purification capacity of iron mine soils due to synergistic effects of biosolids and plants.
\end{abstract}

E. N. Cele

nkosinathie_cele75@yahoo.com

1 Unit for Environmental Sciences and Management, Faculty of Natural Sciences, North-West University (Potchefstroom Campus), Private Bag X6001, Potchefstroom 2520, South Africa
Keywords Mining $\cdot$ Biosolids disposal $\cdot$ Soil physicochemical conditions

\section{Introduction}

The mining industry is an important sector considered by many countries as necessary for economic development, especially in Southern Africa where it has been one of the mainstays for over a century (McCulloch 2003). Although mining can bring much economic prosperity (Yan et al. 2013; Wolff et al. 2011), large areas of dereliction often result once mining has ceased (Stuben et al. 2001; Tordoff et al. 2000), due to land clearance, transportation activities and generation of vast amounts of mine wastes on top of existing vegetation (Yan et al. 2013).

The Ngwenya iron ore mine site in Swaziland is no exception. The site is currently in a derelict state as a result of open-pit mining operations that were carried out from 1964 (Waïtzenegger et al. 1970; Sneesby 1968) to 1980 (McLoughlin and Mehra 1988) and also from 2011 to present (Swaziland Environmental Authority [SEA] 2011). Sites degraded by mining operations, such as Ngwenya (iron ore mine dumps), Dvokolwako (diamond mine dumps), Havelock (asbestos mine dumps) and Maloma (coal mine dumps), were recently (2013) considered by the Swaziland Water Services Corporation (SWSC) as an opportunity that can alleviate the Corporation's biosolids disposal problems. Presently, the disposal of biosolids in Swaziland is a problem to which no permanent solution has yet been identified. In fact, the handling of biosolids and the achievement of environmentally sound and economically feasible disposal strategies are currently major issues in wastewater treatment, not only in Swaziland but in many places around the world (Deepesh et al. 2014; Fytili and Zabanitou 2008; Contin et al. 
2012). The controlled application of biosolids in mine sites can greatly improve soil physicochemical conditions since these organic residues contain organic matter $(\mathrm{OM})$ that acts as a soil conditioner which can improve soil aeration, waterholding capacity (Bourioug et al. 2014; Hua et al. 2008; Wong et al. 1998, etc.), contributing to erosion control, slope stabilization (Luczkiewicz 2006) and aggregate stability (Bozkurt et al. 2010). Improvements in soil conditions could enhance re-establishment of plants, which are important in reducing mobility and bioavailability of toxic metal in soils (Zodrow 1999; Wong 2003; Santibáñez et al. 2008), thus preventing migration of trace elements to groundwater or their entry into the food chain (Ali et al. 2013).

The utilization of biosolids, therefore, in the above manner is an economical and practical way to recycle sewage sludge (Nicolas et al. 2014; Terrason et al. 2010; Ogleni and Ozdemir 2010; Contin et al. 2012) rather than dumping it in landfills or burning it in incinerators (Terrason et al. 2010). This also serves the dual purpose of recycling biosolids while remediating soil volume lost through mining (Waterhouse et al. 2014).

However, since land application of biosolids is still generally regarded as controversial due to possible human health and environmental risks (Luczkiewicz 2006), on account of elevated metal concentrations contained therein (Bourioug et al. 2014; Hua et al. 2008; Forsberg and Ledin 2006; etc.), the SWSC commissioned a number of studies to investigate the impacts of biosolids in mine soils with regard to various aspects including soil physicochemical conditions, plant establishment and growth and metal accumulation in plants. Although they are important, these aspects are based on conventional physical and chemical soil analyses and visually distinguishable aboveground indicators, such as vegetation, and are unable to account for soil microbiota, which are the basis of terrestrial ecosystems (Claassens et al. 2008). Therefore, in order to holistically assess the ameliorative influence of biosolids, it was deemed necessary to study belowground bioindicators in addition to aboveground changes. Thus, the purpose of this study was to investigate soil enzyme activities in iron ore tailings subsequent to the application of biosolids and plant establishment. The study was carried out at the North-West University (Potchefstroom Campus), South Africa, between September 2014 and May 2015.

\section{Materials and methods}

In the previous study (Cele and Maboeta 2016), the influence of biosolids on soil physicochemical status was studied. The current study investigates the influence of biosolids on soil enzyme activities; however, since enzymes are studied on soils from the previous study, some methods and data from the previous study are shown in the current study in order to demonstrate relationship between biosolids, soil physicochemical status and soil enzymes.

\section{(1) Sample collection and preparation}

Bulk samples of iron ore tailings were collected at $\mathrm{Ng}$ wenya iron ore mine (latitude $26^{\circ} 12^{\prime} 20.97^{\prime \prime}$ and longitude $\left.31^{\circ} 01^{\prime} 56.89^{\prime \prime}\right)$. Biosolids were collected at Ezulwini wastewater treatment plant (latitude $26^{\circ} 24^{\prime} 11.94^{\prime \prime}$ and longitude $\left.31^{\circ} 11^{\prime} 56.53^{\prime \prime}\right)$. Undisturbed topsoil was also collected at a distance of $2.5 \mathrm{~km}$ away from the iron ore tailings dumps, from the top 0-20 cm layer. Undisturbed topsoil was used as reference soil (RS). Samples were airdried for 14 days, after which they were crushed and blended together using mortar and pestle and passed through a 2-mm sieve.

\section{(2) Design of plant trials}

In many mine soil remediation projects, the use of stockpiled topsoil is an important aspect of mine soil remediation, especially when mixed with biosolids (Brown et al. 2014; Sydnor and Redente 2002). According to Ngwenya mine authorities, topsoil will be used in re-vegetation of the site subsequent to mining (SEA 2011). However, it is a known fact that replacement topsoil may not always be available (Butt et al. 1995). In view of these realities, three plant trials were conducted. In the first trial, biosolids and undisturbed soil were added to tailings at 0 (Control), 10, 25, 50, 75 and $100 \mathrm{tha}^{-1}$; this was labelled as the TUSB treatment (tailings, plus undisturbed soil plus biosolids). In the second trial, biosolids only were added to tailings at the same rates; this was called TB treatment (tailings plus biosolids). Each treatment was replicated three times. In order to ensure consistency, substrates were mixed in one large container for each treatment and were left to equilibrate for 30 days. Once weekly, the mixtures were turned over and mixed thoroughly. After 30 days, the substrate from each large container was distributed into plant growth pots. To prevent the substrate from escaping through the holes at the bottom and the possibility of roots growing out of the pots (Hu et al. 2013a, b), pieces of frost cloth were placed at the bottom before placing the substrate. Since the $100 \%$ water-holding capacity (WHC) of tailings was determined prior to trial set-up, each pot containing the mixed substrate was adjust to $60 \%$ WHC using tap water and left to stabilize for 2 days (Ruiz et al. 2009; Wen et al. 2004; Wang et al. 2007). Thereafter, 25 seeds (Grant et al. 2002) of Cynodon dactylon were sown $2 \mathrm{~cm}$ deep (Du et al. 2014) in each pot.

In the third trial, seeds of the same plant species were sown in RS, which was collected from the vicinity of the mine site but in an undisturbed area. Biosolids were not 
added to RS. In order to assess the extent of the ameliorative influence of biosolids, results from trial 1 and 2 were to be compared to results from trial 3 (RS). This was based on the Society for Ecological Restoration's definition of ecological restoration, which is the process of assisting the recovery of an ecosystem towards a reference state (Waterhouse et al. 2014).

After 4 weeks of initiation of all trials (Grant et al. 2002), seedlings in all trials were thinned to ten plants per pot (Seleiman et al. 2012; Jiemin and Wong 2013). Plants were watered twice weekly (Rate et al. 2004; Waterhouse et al. 2014) and were randomly placed in the greenhouse (Perez-de-Mora et al. 2007; Verdugo et al. 2011; Meeinkuirt et al. 2012) and relocated once a week. After 12 weeks, plant trials were terminated.

Plants were cautiously removed, and the roots were gently shaken to free tightly adhering soil (Dongmei and Changqun 2008). Roots and shoots were divided and carefully washed with tap water in order to remove any remaining soil, dust deposits and surface substrates (Novo et al. 2013). Immediately after cleaning, the fresh weight of roots and shoots for each plant in each pot was determined by measuring on a scale. Plants were dried in the oven at $80{ }^{\circ} \mathrm{C}$ for $48 \mathrm{~h}$ and thereafter removed and cooled down to room temperature. The dry weights of roots and shoots were determined again by weighing on a scale.

\section{(2) Soil preservation and enzyme analysis}

About $1 \mathrm{~kg}$ of soil from each replicate pot was placed in tightly sealed plastic bags while still moist. Samples were then placed in a refrigerator at $4{ }^{\circ} \mathrm{C}$ (Gianfreda et al. 2005; Lai et al. 1999; Li et al. 2015; Perez-de-Mora et al. 2005; Jin et al. 2014; Qu et al. 2011; Romero et al. 2005; Moreno et al. 2009; Koo et al. 2012) to preserve biological properties (Claassens et al. 2008; Maboeta et al. 2006), and chemical analysis was carried out within 3 weeks. Immediately prior to analysis, samples were removed from the refrigerator, placed on petri dishes and laid on the table for air-drying. The following morning, samples were thoroughly crushed with pestle and mortar and passed through $a<2 \mathrm{~mm}$ sieve. Each sample was analysed in triplicate (control, sub-samples 1 and 2) (Sastre et al. 1996) and for each sample, three types of enzymes were investigated, namely $\beta$-glucosidase, alkaline phosphatase and urease. Briefly, the estimation of $\beta$-glucosidase was based on the determination of the released $p$-nitrophenol, after the incubation of soil with $p$-nitrophenyl glucoside solution for $1 \mathrm{~h}$ at $37^{\circ} \mathrm{C}$ (Dick et al. 1996). For the estimation of alkaline phosphatase, the procedure was based on the determination of $p$-nitrophenol released after the incubation of soil with $p$-nitrophenyl phosphate for $1 \mathrm{~h}$ at $37{ }^{\circ} \mathrm{C}$ (Tabatabai 1994). For the urease enzyme, the method was based on colorimetric determination of released ammonia after the incubation of soil samples with urea solution for $2 \mathrm{~h}$ at $37^{\circ} \mathrm{C}$ (Kandeler and Gerber 1988).

\section{(3) Soil chemical analysis}

Total metals were determined in accordance with protocols provided by the USEPA, in Method 3050b (1996). This was done by first digesting soil samples in nitric acid $\left(\mathrm{HNO}_{3}\right)$ and hydrogen peroxide $\left(\mathrm{H}_{2} \mathrm{O}_{2}\right)$. The resultant digestate was then analysed by inductively coupled plasma mass spectrometry (ICP-MS).

WHC was calculated according to the ISO/FDIS 17512-1:2007 (E) method as described by the International Organization for Standardization (ISO) (2007). Acidity was determined by measuring $\mathrm{pH}\left(\mathrm{H}_{2} \mathrm{O}\right)$ in $1: 2.5$ soil/water ratio suspension on a mass basis and $\mathrm{pH}(\mathrm{KCl})$ in $1: 2.5$ $10 \mathrm{~mol} \mathrm{KCl}$ solution. Salinity was determined by measuring electrical conductivity (EC). For cation exchange capacity (CEC), exchangeable plus water soluble cations $\left(\mathrm{K}^{+}, \mathrm{Ca}^{2+}, \mathrm{Na}^{+}, \mathrm{Mg}^{2+}\right)$ and anions $\left(\mathrm{NH}_{4}{ }^{+}, \mathrm{NO}_{3}{ }^{-}, \mathrm{PO}_{4}{ }^{-}\right)$, the ammonium acetate $\left(1 \mathrm{~mol} \mathrm{dm}^{-3}, \mathrm{pH}\right.$ 7) and Bray 1 methods were used to determine these parameters (Soil Science Society of South Africa 1990). OM matter was determined by the loss on ignition (LOI) method, as described by Nelson and Sommers (1982) and Wilke (2010).

\section{(4) Statistical analysis}

The SPSS statistical software version 22 (2015) was used in all data analysis in this study. The Kolmogorov-Smirnov $(\mathrm{K}-\mathrm{S})$ test was used to test the distribution of data. For normally distributed data, the analysis of variance ANOVA (at a significance level of 0.05 ) and homogeneity of variance test were carried out. Differences of means within treatments were investigated by the Tukey's $B$ test, and the findings were checked with the Games-Howell procedure. In order to assist in interpreting results, several options for one-way ANOVA were included in the tests, and these were descriptive statistics (table of means, standard deviations, ranges, confidence intervals for each group and means plots). The Brown's and Welch's $F$-ratio versions were selected in order to take care of the effects of nonconformity to homogeneity of variance. Non-normally distributed data were analysed by the nonparametric version of one-way independent ANOVA (Kruskal-Wallis test) (Field 2009).

\section{Results and discussion}

A pre-trial assessment of soil physicochemical status and soil enzyme activities was conducted on tailings, RS and biosolids, and the results are presented in Tables 1 and 2 .

Subsequent to plant growth trials, it was observed that the application of biosolids (with or without soil) followed 
Table 1 Pre-trial

characterization of physicochemical status of iron ore tailings, reference soil and biosolids $(n=3)$

\begin{tabular}{|c|c|c|c|}
\hline Soil parameters & Iron ore tailings & Reference soil & Biosolids \\
\hline $\mathrm{Ca}^{2+}\left(\mathrm{cmol}(+) \mathrm{kg}^{-1}\right)$ & 0.24 & 0.62 & 8.90 \\
\hline $\mathrm{Mg}^{2+}\left(\mathrm{cmol}(+) \mathrm{kg}^{-1}\right)$ & 0.49 & 0.49 & 1.40 \\
\hline $\mathrm{K}^{+}\left(\mathrm{cmol}(+) \mathrm{kg}^{-1}\right)$ & 0.05 & 0.41 & 0.45 \\
\hline $\mathrm{Na}^{+}\left(\mathrm{cmol}(+) \mathrm{kg}^{-1}\right)$ & ND & 0.03 & 0.06 \\
\hline $\mathrm{PO}_{4}^{-}\left(\mathrm{mg} \mathrm{L}^{-1}\right)$ & ND & ND & ND \\
\hline $\mathrm{NO}_{3}^{-}\left(\mathrm{mg} \mathrm{L}^{-1}\right)$ & 2007.20 & 82.47 & 86152 \\
\hline $\mathrm{NH}_{4}^{+}\left(\mathrm{mg} \mathrm{L}^{-1}\right)$ & 7.81 & 9.11 & 121.7 \\
\hline $\mathrm{CEC}\left(\mathrm{cmol}(+) \mathrm{kg}^{-1}\right)$ & 8.38 & 24.40 & 35.29 \\
\hline $\mathrm{pH}\left(\mathrm{H}_{2} \mathrm{O}\right)$ & 4.92 & 4.62 & 4.24 \\
\hline $\mathrm{OM}(\% \mathrm{C})$ & 0.02 & 4.19 & 17.66 \\
\hline $\mathrm{EC}\left(\mathrm{dS} \mathrm{m}{ }^{-1}\right)$ & 0.25 & 0.17 & 3.82 \\
\hline WHC (100\% ml) & 1.24 & 2.63 & 2.62 \\
\hline \multicolumn{4}{|l|}{ Heavy metals $\left(\mathrm{mg} \mathrm{kg}^{-1}\right)$} \\
\hline $\mathrm{Ni}$ & 73.50 & 107.70 & 41.35 \\
\hline $\mathrm{Cu}$ & 18.54 & 43.70 & 341.25 \\
\hline $\mathrm{Zn}$ & 13.25 & 22.82 & 1146.25 \\
\hline $\mathrm{Cd}$ & 0.05 & 0.05 & 1.29 \\
\hline $\mathrm{Hg}$ & 0.13 & 0.50 & 3.33 \\
\hline $\mathrm{Pb}$ & 3.83 & 11.50 & 67.19 \\
\hline
\end{tabular}

Table 2 Pre-trial characterization of soil enzyme activities in iron ore tailings, reference soil and biosolids $(n=3)$

\begin{tabular}{llll}
\hline Experimental soils & \multicolumn{2}{l}{ Soil enzymes } & \\
\cline { 2 - 4 } & $\begin{array}{l}\text { Alkaline phosphatase } \\
(\mathrm{mg} \mathrm{PN} / \mathrm{kg} \text { soil/h) }\end{array}$ & $\begin{array}{l}\beta \text {-glucosidase } \\
(\mathrm{mg} \text { PN/kg soil/h) }\end{array}$ & $\begin{array}{l}\text { Urease }(\mathrm{mg} \text { NH4-N/kg } \\
\text { soil/2 h) }\end{array}$ \\
\hline RS & 2117.05 & 331.07 & 1.13 \\
Biosolids & 4433.92 & 382.41 & 1.30 \\
Iron ore tailings & 225.40 & 60.77 & 0.23 \\
\hline
\end{tabular}

Table 3 Mean $( \pm$ SE, $n=3)$ soil enzyme activities in the TUSB treatment after 12 weeks of plant growth trial

\begin{tabular}{lccc}
\hline Treatment $\left(\mathrm{t} \mathrm{ha}^{-1}\right)$ & \multicolumn{2}{l}{ Soil enzymes } & \\
\cline { 2 - 4 } & $\begin{array}{l}\text { Alkaline phosphatase } \\
(\mathrm{mg} \mathrm{PN} / \mathrm{kg} \mathrm{soil} / \mathrm{h})\end{array}$ & $\begin{array}{l}\beta \text {-glucosidase }(\mathrm{mg} \\
\text { PN/kg soil/h) }\end{array}$ & $\begin{array}{l}\text { Urease }(\mathrm{mg} \mathrm{NH}-\mathrm{N} / \mathrm{kg} \\
\text { soil/2 h) }\end{array}$ \\
\hline RS & $1069.57 \pm 2.77$ & $1552.55 \pm 242.10$ & $119.00 \pm 8.37$ \\
0 (control) & $194.25 \pm 2.85$ & $27.90 \pm 2.92$ & $6.39 \pm 1.07$ \\
10 & $227.62 \pm 2.73$ & $67.21 \pm 10.62$ & $5.59 \pm 1.85$ \\
25 & $199.36 \pm 2.69$ & $107.93 \pm 2.48$ & $9.25 \pm 0.84$ \\
50 & $350.46 \pm 2.69$ & $248.38 \pm 29.84$ & $31.38 \pm 8.66$ \\
75 & $181.41 \pm 2.96$ & $286.63 \pm 22.04$ & $24.21 \pm 4.87$ \\
100 & $305.14 \pm 2.92$ & $471.55 \pm 39.12$ & $25.95 \pm 1.25$ \\
\hline
\end{tabular}

by the establishment of plants on iron mine soils led to significant $(p<0.05)$ increases in the activities of alkaline phosphatase, $\beta$-glucosidase and urease soil enzymes, as listed in Tables 3 and 4. However, in the TUSB treatment, $p$ was $>0.05$ for alkaline phosphatase activities at 0 and $25 \mathrm{t} \mathrm{ha}^{-1}, \beta$-glucosidase activities at 50 and $75 \mathrm{t} \mathrm{ha}^{-1}$ and urease activities at 0 and $10 \mathrm{tha}^{-1}$. In the TB treatment, $p$ was also $>0.05$ for alkaline phosphatase activities at 10 and $100 \mathrm{t} \mathrm{ha}^{-1}$ and urease activities at 0 and $10 \mathrm{t} \mathrm{ha}^{-1}$.

In control soil (planted tailings without biosolids), $\beta$ glucosidase activities were not detectible; however, in all planted tailings that received biosolids, there were 
Table 4 Mean $( \pm$ SE, $n=3)$ soil enzyme activities in the TB treatment after 12 weeks of plant growth trial

\begin{tabular}{|c|c|c|c|}
\hline \multirow[t]{2}{*}{ Treatment $\left(\mathrm{t} \mathrm{ha}^{-1}\right)$} & \multicolumn{3}{|l|}{ Soil enzymes } \\
\hline & $\begin{array}{l}\text { Alkaline phosphatase } \\
\text { (mg PN/kg soil/h) }\end{array}$ & $\begin{array}{l}\beta \text {-glucosidase } \\
(\mathrm{mg} \mathrm{PN} / \mathrm{kg} \text { soil/h) }\end{array}$ & $\begin{array}{l}\text { Urease } \\
(\mathrm{mg} \mathrm{NH} 4-\mathrm{N} / \mathrm{kg} \text { soil/2 h) }\end{array}$ \\
\hline RS & $1069.57 \pm 2.77$ & $1552.55 \pm 242.10$ & $119.00 \pm 8.37$ \\
\hline 0 (control) & $194.25 \pm 2.85$ & $27.90 \pm 2.92$ & $6.39 \pm 1.06$ \\
\hline 10 & $277.66 \pm 2.85$ & $46.46 \pm 3.25$ & $8.09 \pm 1.34$ \\
\hline 25 & $169.22 \pm 2.89$ & $85.79 \pm 9.25$ & $9.08 \pm 1.63$ \\
\hline 50 & $220.57 \pm 2.74$ & $130.39 \pm 3.93$ & $10.93 \pm 2.14$ \\
\hline 75 & $222.63 \pm 3.06$ & $185.05 \pm 21.55$ & $18.68 \pm 4.34$ \\
\hline 100 & $278.56 \pm 2.97$ & $314.97 \pm 39.52$ & $25.44 \pm 1.31$ \\
\hline
\end{tabular}

Table 5 Mean $( \pm \mathrm{SE}, n=3)$ concentrations/levels of soil parameters subsequent to 12 weeks of plant growth trial in the TUSB treatment

\begin{tabular}{|c|c|c|c|c|c|c|}
\hline \multirow[t]{2}{*}{ Treatment $\left(\mathrm{t} \mathrm{ha}{ }^{-1}\right)$} & \multicolumn{6}{|c|}{ Soil parameters ${ }^{\mathrm{a}}$} \\
\hline & $\mathrm{Ca}^{2+}$ & $\mathrm{PO}_{4}^{-}$ & $\mathrm{OM}$ & WHC & CEC & $\mathrm{pH}$ \\
\hline $\mathrm{RS}$ & $0.99 \pm 0.02$ & $0.09 \pm 0.03$ & $3.94 \pm 0.04$ & $2.87 \pm 0.13$ & $16.28 \pm 1.10$ & $5.17 \pm 0.06$ \\
\hline 0 (control) & $0.36 \pm 0.03$ & $0.01 \pm 0.00$ & $0.21 \pm 0.02$ & $1.98 \pm 0.03$ & $6.53 \pm 0.42$ & $6.66 \pm 0.13$ \\
\hline 10 & $0.51 \pm 0.04$ & $0.10 \pm 0.25$ & $0.57 \pm 0.02$ & $2.07 \pm 0.01$ & $9.74 \pm 1.05$ & $5.80 \pm 0.04$ \\
\hline 25 & $0.58 \pm 0.01$ & $0.09 \pm 0.24$ & $0.61 \pm 0.03$ & $2.10 \pm 0.02$ & $11.97 \pm 0.88$ & $5.80 \pm 0.04$ \\
\hline 50 & $0.67 \pm 0.03$ & $0.12 \pm 0.09$ & $0.97 \pm 0.03$ & $2.78 \pm 0.04$ & $10.51 \pm 0.95$ & $5.49 \pm 0.02$ \\
\hline 75 & $0.78 \pm 0.03$ & $0.33 \pm 0.06$ & $1.15 \pm 0.03$ & $2.85 \pm 0.03$ & $12.27 \pm 0.62$ & $5.40 \pm 0.03$ \\
\hline 100 & $1.17 \pm 0.41$ & $0.08 \pm 0.06$ & $1.45 \pm 0.08$ & $3.14 \pm 0.23$ & $11.23 \pm 1.14$ & $5.82 \pm 0.04$ \\
\hline
\end{tabular}

${ }^{a}$ For units, see Table 2

Table 6 Mean $( \pm \mathrm{SE}, n=3)$ concentrations/levels of soil parameters subsequent to 12 weeks of plant growth trial in the TB treatment

\begin{tabular}{|c|c|c|c|c|c|c|}
\hline \multirow[t]{2}{*}{ Treatment $\left(\mathrm{t} \mathrm{ha}^{-1}\right)$} & \multicolumn{6}{|c|}{ Soil parameters ${ }^{\mathrm{a}}$} \\
\hline & $\mathrm{Ca}^{2+}$ & $\mathrm{PO}_{4}^{-}$ & $\mathrm{OM}$ & WHC & CEC & $\mathrm{pH}$ \\
\hline $\mathrm{RS}$ & $0.99 \pm 0.02$ & $0.09 \pm 0.03$ & $3.94 \pm 0.04$ & $2.87 \pm 0.13$ & $16.28 \pm 1.10$ & $5.17 \pm 0.06$ \\
\hline 0 (control) & $0.36 \pm 0.03$ & $0.01 \pm 0.00$ & $0.22 \pm 0.02$ & $1.98 \pm 0.03$ & $6.53 \pm 0.42$ & $6.66 \pm 0.13$ \\
\hline $10 \mathrm{t} \mathrm{ha}^{-1}$ & $0.56 \pm 0.04$ & $0.49 \pm 0.25$ & $0.55 \pm 0.02$ & $1.96 \pm 0.01$ & $9.78 \pm 1.05$ & $5.76 \pm 0.04$ \\
\hline $25 \mathrm{t} \mathrm{ha}^{-1}$ & $0.61 \pm 0.01$ & $0.55 \pm 0.24$ & $0.54 \pm 0.03$ & $2.06 \pm 0.02$ & $8.86 \pm 0.88$ & $5.84 \pm 0.04$ \\
\hline $50 \mathrm{t} \mathrm{ha}^{-1}$ & $0.80 \pm 0.03$ & $0.42 \pm 0.09$ & $0.82 \pm 0.03$ & $1.98 \pm 0.04$ & $13.02 \pm 0.95$ & $5.72 \pm 0.02$ \\
\hline $75 \mathrm{tha}^{-1}$ & $0.90 \pm 0.03$ & $0.68 \pm 0.06$ & $1.01 \pm 0.03$ & $2.33 \pm 0.03$ & $11.57 \pm 0.62$ & $5.63 \pm 0.03$ \\
\hline $100 \mathrm{t} \mathrm{ha}^{-1}$ & $1.19 \pm 0.04$ & $1.41 \pm 0.20$ & $1.42 \pm 0.03$ & $2.08 \pm 0.05$ & $9.23 \pm 0.61$ & $6.07 \pm 0.04$ \\
\hline
\end{tabular}

${ }^{\mathrm{a}}$ For units, see Table 2

significant increases $(p<0.05)$ in $\beta$-glucosidase activities, and this was consistent with each increase in biosolids application. At $100 \mathrm{t} \mathrm{ha}^{-1}$ in both treatments, $\beta$-glucosidase activities were higher than alkaline phosphatase and urease activities, reaching 471.55 and $314.97 \mathrm{mg} \mathrm{PN} / \mathrm{kg}$ soil/h (TUSB treatment and TB treatment, respectively). Although urease enzyme activities were the lowest in both treatments, increases were nonetheless significant $(p<0.05)$, particularly from $25-100 \mathrm{t} \mathrm{ha}^{-1}$. Generally, urease activities increased with each increase in biosolids application rate. Alkaline phosphatase activities were also higher in all planted tailings that received biosolids $\left(10-100 \mathrm{t} \mathrm{ha}^{-1}\right)$ than in control $\left(0 \mathrm{t} \mathrm{ha}^{-1}\right)$, although increases were not consistent.

The observed increases in soil enzyme activities were attributed to improvements in soil physicochemical conditions, due to the application of biosolids and the presence of plants. According to Kizilkaya et al. (2011), soil enzyme activities are affected by soil conditions including $\mathrm{pH}$, ion conditions, temperature, soil texture, OM content, CEC and 
microbial biomass. In this study, there were significant $(p<0.05)$ increases in soil parameters related to soil fertility such as $\mathrm{OM}$, phosphorus $\left(\mathrm{PO}_{4}^{-}\right)$, calcium $\left(\mathrm{Ca}^{2+}\right)$, CEC and WHC. At $100 \mathrm{tha}^{-1}$ (TUSB treatment), $\mathrm{Ca}^{2+}$ and WHC were significantly higher $(p<0.05)$ than in RS. In the TB treatment, $\mathrm{Ca}^{2+}$ and $\mathrm{PO}_{4}{ }^{-}$were also significantly higher $(p<0.05)$ at $100 \mathrm{t} \mathrm{ha}^{-1}$ than in RS, as listed in Tables 5 and 6.

$\mathrm{OM}$ is known to result in positive changes in physical and chemical soil properties, such as water-holding and sorption capacities, nutrient content and availability (Zhao et al. 2013) and CEC (Khan 2002). CEC in control was $6.53 \mathrm{cmol}(+) \mathrm{kg}^{-1}$; however, in tailings that received biosolids, it increased to $12.27 \mathrm{cmol}(+) \mathrm{kg}^{-1}$. According Jones (2012), CEC within $11-50 \mathrm{cmol}(+) \mathrm{kg}^{-1}$ is highly desirable since it is associated with high OM content, high capacity to hold plant nutrient elements within the soil profile and high WHC.

With regard to acidity, $\mathrm{pH}$ decreased (at 50 and $75 \mathrm{t} \mathrm{ha}^{-1}$ ) from the very slightly acidic range (also referred to as neutral range, 6.5-7.0) to the very strongly acidic range $(<5.5)$. At $100 \mathrm{t} \mathrm{ha}^{-1}$, however, $\mathrm{pH}$ increased again to the medium acidic range (5.5-6.0) (TUSB treatment). In the $\mathrm{TB}$ treatment, $\mathrm{pH}$ remained in the medium acidic range (5.5-6.0) from 10 to $75 \mathrm{t} \mathrm{ha}^{-1}$ and increased to the slightly acidic range (6.0-6.5) at $100 \mathrm{tha}^{-1}$. The decrease in $\mathrm{pH}$ was attributed biosolids application because according to the results of pre-trial assessment on all experimental soils, biosolids were strongly acidic ( $\mathrm{pH} 4.24)$ as listed in Table 2. Even though biosolids were strongly acidic, $\mathrm{pH}$ in all biosolid-treated tailings did not fall below 5.4. Also, at the highest application rate $\left(100 \mathrm{tha}^{-1}\right), \mathrm{pH}$ was 5.82 (TUSB treatment) and 6.07 (TB treatment). These results were rather favourable because a $\mathrm{pH}$ level of 5.0 or higher is suitable for $\mathrm{N}$ fixation (Maiti and Saxena 1998). Most importantly, $\mathrm{pH}$ was higher in all biosolid-treated tailings than in RS.

Salinity also remained between 0 and $2 \mathrm{dS} \mathrm{m}^{-1}$, which is classified as non-saline and optimum for plant growth (Maiti and Saxena 1998). According to Meeinkuirt et al. (2012), $0.2 \mathrm{dS} \mathrm{m}^{-1}$ is the standard level of acceptable salinity, while soils with electrical conductivity values $>4 \mathrm{dS} \mathrm{m}^{-1}$ are considered saline (Hodson and Donner 2013).

The positive effects of biosolids on soil enzymes, due to improvements in soil physicochemical conditions, have also been observed in many studies e.g. Sastre et al. (1996), Lai et al. (1999), Kizilkaya and Bayrakli (2005), Perez-deMora et al. (2005) and Fernandes et al. (2005).

Notably, despite significant increases in soil enzyme activities in the TUSB and TB treatments, the activities of the same soil enzymes remained higher in RS than in all soils in the TUSB and TB treatments. This was ascribed to the fact that $\mathrm{OM}$ was highest in RS than in all soils in the TUSB and TB treatments. According to Chang and Chiu (2015), high soil OM sustains high microbial biomass and high enzyme activities.

In addition to the application of biosolids, another possible explanation for the observed increases in soil enzyme activities was the presence of plants. Garcia-Gill et al. (2000) also found that enzyme activities were enhanced by the combination of plants and organic amendments because both organic waste incorporation and root exudates improved soil porosity and aeration. According to $\mathrm{Hu}$ et al. (2013a, b), plants affect soil enzyme activities in two different ways. Firstly, plants affect the soil biota by influencing the quantity and quality of organic substrates that reach the soil. Secondly, plants take up some heavy metals from soil, which may result in the reduction in heavy metal toxicity on soil enzymes.

Despite positive changes in soil enzyme activities, the application of biosolids led to significant increases $(p<0.05)$ in $\mathrm{Cu}, \mathrm{Zn}$ and $\mathrm{Pb}$ as shown in Fig. 1. However, $\mathrm{Ni}, \mathrm{Cu}$ and $\mathrm{Pb}$ concentrations were lower in all biosolidtreated tailings than in $\mathrm{RS}$. $\mathrm{Cd}$ and $\mathrm{Hg}$ concentrations were $<1 \mathrm{mg} \mathrm{kg}^{-1}$ in all soils (RS, TUSB and TB). In the TB treatment, $\mathrm{Zn}$ concentrations were higher $\left(37.61 \mathrm{mg} \mathrm{kg}^{-1}\right)$ than in RS $\left(20.22 \mathrm{mg} \mathrm{kg}^{-1}\right)$ even at the lowest application rate $\left(10 \mathrm{tha}^{-1}\right)$, and increased with each increase in biosolids application rate up to $96.03 \mathrm{mg} \mathrm{kg}^{-1}$. The increases in $\mathrm{Zn}$ concentrations were ascribed to biosolids application because it has been stated that sewage sludges may contain high concentrations of $\mathrm{Zn}$. It has been shown in long-term experiments that $\mathrm{Zn}$ is the most bioavailable metal in soils treated with sewage sludges (Bradl 2005).

Generally, metals are known to inhibit soil enzyme activities (Angelovicova et al. 2014; Pan and Yu 2011; Belyaeva et al. 2005; Kizilkaya and Bayrakli 2005; etc.); however, according to the results obtained in this study, enzyme activities were not affected by increases in metal concentrations. Instead, $\beta$-glucosidase and urease enzyme exhibited increases with each increase in biosolids application. The apparent resistance of soils enzymes to metals can be attributed to a number of factors. Firstly, improvements in soil physicochemical conditions, especially OM, may have inactivated the impacts of metals. According to Gülser and Erdogan (2008), OM-metal complexes occur in $\mathrm{OM}$ and soil solutions and would prevent the metals from interacting directly with the active sites of enzymes. Kizilkaya and Bayrakli (2005) found that sludge application increased available metal $(\mathrm{Cu}, \mathrm{Ni}, \mathrm{Pb}$ and $\mathrm{Zn})$ contents in the soils. However, while this was the case, it was concluded that the full extent of the negative effects of metals on enzymatic activities might have been masked by the positive effects of sewage sludge on soil physical and chemical properties. 
Fig. 1 Mean $( \pm \mathrm{SE}, n=3)$ metal concentrations in the TUSB (a) and TB (b) treatments subsequent to 12 weeks of plant growth trials
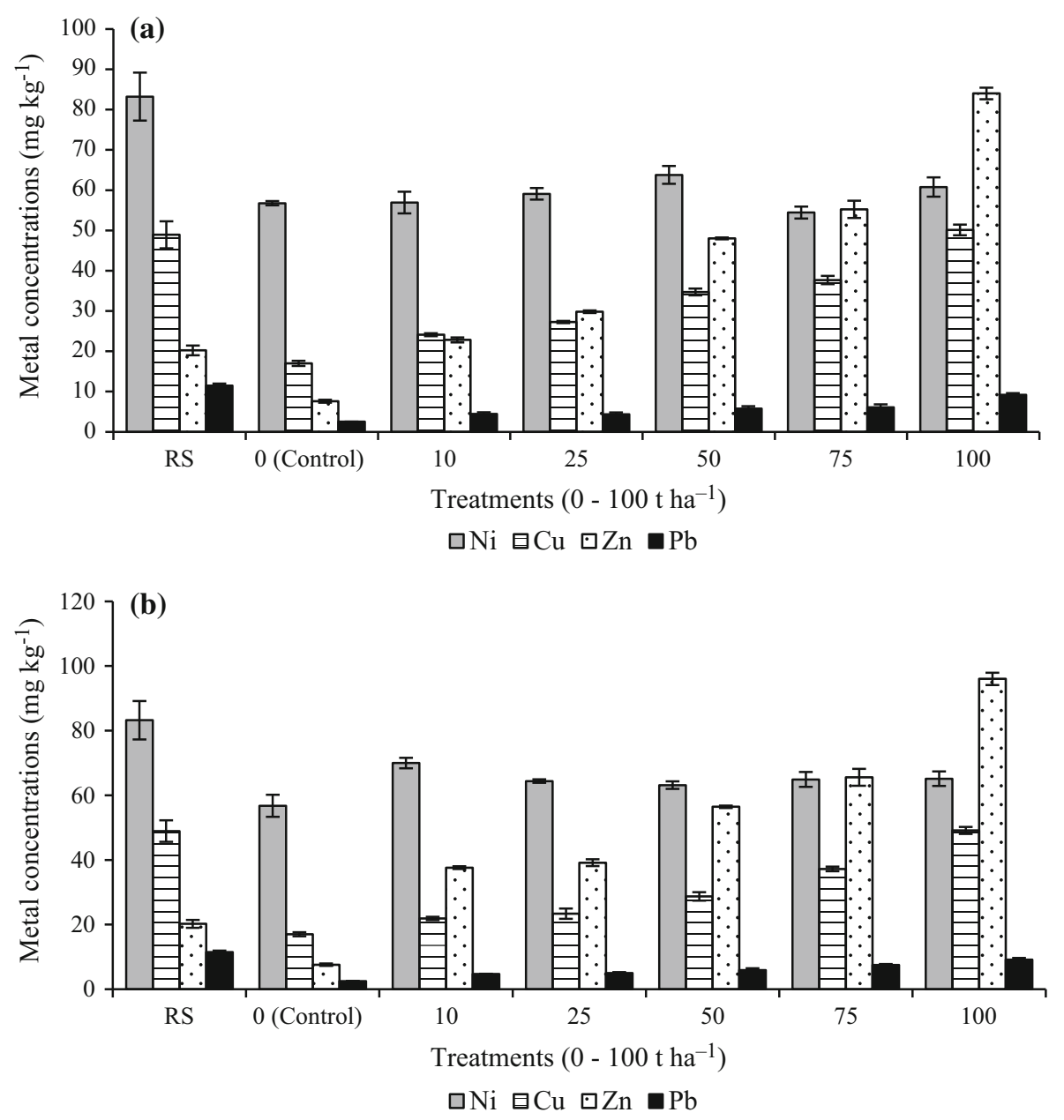

Secondly, the essentiality of $\mathrm{Cu}$ and $\mathrm{Zn}$ could be another factor that enabled soil enzymes activities to increase despite increases in metals. According to Alloway (2013), $\mathrm{Zn}$ is a constituent of several enzymes with roles in carbohydrate and protein synthesis. In fact, many enzymes cannot function without $\mathrm{Zn}$ (Bellas et al. 2012). Cu is also an essential trace element that is vital to the health of all living organisms (humans, plants, animals and micro-organisms). It is found in a variety of enzymes and proteins, including the cytochrome $\mathrm{c}$ oxidase and certain superoxide dismutases (Oorts 2012). It can be said, therefore, that although $\mathrm{Cu}$ and $\mathrm{Zn}$ were increased in soil by addition of biosolids, they probably remained within a tolerable range to soil enzymes. In fact, in many studies (e.g. Bellas et al. 2012; Dewey et al. 2012; Hagmann et al. 2015; Hu et al. 2013a, b), the inhibition of soil enzymes activities was only observed at higher metal concentrations than what was observed in this study.

Thirdly, the manner in which metals were added to tailings may also explain the seeming lack of impacts on soil enzymes. It has been said that metals in sewage sludge are invariably strongly complexed with mineral and organic components of the sludge and are, therefore, considered to be far less biologically available than metals in salts (Speir 2008; Oorts 2012). Mertens and Smolders (2013) found that metal salts are, in fact, capable of overestimating toxicity. The application of sewage sludge or manure to a soil may increase metal-binding capacity of the soil as these products contain $\mathrm{OM}$ and $\mathrm{Fe}$ or $\mathrm{Al}$ oxyhydroxides, which all have metal-binding properties. Additionally, metals present in these materials have a different speciation, and typically, they have lower availability compared to metal salts. Dindar et al. 2015 observed that soil enzyme activities were not affected by sludge-derived metals even for the highest sludge doses $\left(200 \mathrm{t} \mathrm{ha}^{-1}\right)$.

\section{Conclusion}

This study sought to assess soil enzyme activities on iron mine soils subsequent to the application of biosolids and establishment of plants. Results showed that in addition to 
general improvements in soil physicochemical conditions, the combination of biosolids and plants can also lead to significant improvements in soil enzyme activities. Increases in soil enzyme activities were considered to be indicative of improvements in the quality (Rao et al. 2014; Zhang et al. 2013; de Verennes et al. 2010; Moreno et al. 2009; Karaca et al. 2002; Manzano et al. 2014; Zhan and Sun 2014), fertility (Madejón et al. 2001), health and selfpurification capacity (Zhang et al. 2013) of iron mine soils due to biosolids application and plant establishment. This study also showed that while metals are generally still regarded as the most dangerous pollutants that restrict land application of biosolids in many places, soil enzymes may tolerate sewage sludge-derived $\mathrm{Cu}$ and $\mathrm{Zn}$ concentrations of up to 50 and $96 \mathrm{mg} \mathrm{kg}^{-1}$ (respectively).

With regard to Swaziland's current proposals to apply Ezulwini biosolids to iron mine soils as a remediation strategy, the observed improvements in soil physicochemical conditions and soil enzyme activities were considered partly favourable to these plans. Nonetheless, mine soil remediation encompasses a wide range of interlinked below- and aboveground aspects than just soil physicochemical conditions and enzyme activities. Further, it is widely accepted that mine soil remediation should ultimately lead to re-colonization of reclaimed sites by various species of soil-dwelling organisms in order to accelerate soil processes. Therefore, the extent of tolerable metal levels and the impacts thereof on soil organisms cannot be measured only through soil enzymes. For these reasons, we recommend further investigations involving the effects of biosolids on other important soil-dwelling organisms (such as earthworms). The investigation of metal uptake by plants established on biosolid-treated iron mine soils must also be considered. Additionally, since this study was carried out under greenhouse conditions, it may be necessary to repeat these trials under field conditions in order to arrive at more satisfactory conclusions.

Acknowledgments The assistance of the Agricultural Research Council (ARC) (Potchefstroom, South Africa) in soil enzyme analysis is momentously appreciated. This work is part of Ph.D. research funded by the Swaziland Water Services Corporation.

\section{References}

Ali H, Khan E, Sajad M (2013) Phytoremediation of heavy metalsconcepts and applications. Chemosphere 91:869-881

Alloway J (2013) Sources of heavy metals and metalloids in soils. In: Alloway BJ (ed) Heavy metals in soils-trace metals and metalloids in soils and their bioavailability, 3rd edn. Springer, London, pp 11-50

Angelovicova L, Lodenius M, Tulisalo E, Fazekasova D (2014) Effect of heavy metals on soil enzyme activity at different field conditions in Middle Spis mining area (Slovakia). Bull Environ Contam Toxicol 93:670-675
Bellas R, Trasar-Cepeda C, Gil-Sotres F, Leirós MC (2012) Changes in some hydrolase activities in agricultural soils in response to zinc contamination. In: Trasar-Cepeda C, Hernández T, García C, Rad C, González-Carcedo S (eds) Soil enzymology in the recycling of organic wastes and environmental restoration. Springer, Berlin, pp 181-195

Belyaeva ON, Haynes RJ, Birukova OA (2005) Barley yield and soil microbial and enzyme activities as affected by contamination of two soils with lead, zinc or copper. Biol Fertil Soils 41:85-94

Bourioug M, Alaoui-Sossé L, Laffray X, Raouf N, Benbrahim M, Badot PM, Alaoui-Sossé B (2014) Evaluation of sewage sludge effects on soil properties, plant growth, mineral nutrition state, and heavy metal distribution in European Larch Seedlings (Larix decidua). Arab J Sci Eng 39:5325-5335

Bozkurt MA, Yarilgac T, Yazici A (2010) The use of sewage sludge as an organic matter source in apple trees. Pol J Environ Stud 9(2):267-274

Bradl HB (2005) Sources and origins of heavy metals. In: Bradl HB (ed) Heavy metals in the environment. Elsevier, London, pp 1-27

Brown S, Mahoney M, Sprenger M (2014) A comparison of the efficacy and ecosystem impact of residual-based and topsoilbased amendments for restoring historic mine tailings in the TriState mining district. Sci Total Environ 485-486:624-632

Butt KR, Frederickson J, Morris RM (1995) An earthworm cultivation and soil inoculation technique for land restoration. Ecol Eng 4:1-9

Cele EN, Maboeta M (2016) A greenhouse trial to investigate the ameliorative properties of biosolids and plants on physicochemical conditions of iron ore tailings: Implications for an iron ore mine site remediation. J Environ Manage 165:167-174

Chang EH, Chiu CY (2015) Changes in soil microbial community structure and activity in a cedar plantation invaded by moso bamboo. Appl Soil Ecol 91:1-7

Claassens S, van Rensburg PJ, Maboeta MS, van Rensburg L (2008) Soil microbial community function and structure in a postmining chronosequence. Water Air Soil Pollut 194:315-329

Contin M, Goi D, Nobili MD (2012) Land application aerobic sewage sludge does not impair methane oxidation rates of soils. Sci Total Environ 441:10-18

de Varennes A, Cunha-Queda C, Qu G (2010) Amendment of an acid mine soil with compost and polyacrylate polymers enhances enzymatic activities but may change the distribution of plant species. Water Air Soil Pollut 208:91-100

Deepesh V, Verma VK, Suma K, Ajay S, Gnanavelu A, Madhusudanan M (2014) Evaluation of an organic soil amendment generated from municipal solid waste seeded with activated sewage sludge. J Mater Cycles Waste Manage. doi:10.1007/ s10163-014-0329-8

Dewey KA, Gaw SK, Northcott GI, Lauren DR, Hackenburg S (2012) The effects of copper on microbial activity and the degradation of atrazine and indoxacarb in a New Zealand soil. Soil Biol Biochem 52:64-74

Dick RP, Breakwell DP, Turco RF (1996) Soil enzyme activities and biodiversity measurements as integrative microbiological indicators. In: Doran JW, Jones AJ (eds) Methods for assessing soil quality. Soil Science Society of America, Madison, pp 9-17

Dindar E, Sagban FO, Baskaya HS (2015) Evaluation of soil enzyme activities as soil quality indicators in sludge-amended soils. J Environ Biol 36:919-926

Dongmei L, Changqun D (2008) Restoration potential of pioneer plants growing on lead-zinc mine tailings in Lanping, southwest China. J Environ Sci 20:1202-1209

Du Y, He M, Xu M, Yan Z, Zhou Y, Guo G, Nie J, Wang L, Hou H, Li F (2014) Interactive effects between earthworms and maize 
plants on the accumulation and toxicity of soil cadmium. Soil Biol Biochem 72:193-202

Environmental Protection Agency (1996) Method 3050b: acid digestion of sediments, sludges and soils, (revision 2). 1200 Pennsylvania Avenue, N. W. Washington, DC 20460, EPA, USA

Fernandes SAP, Bettiol W, Cerri CC (2005) Effect of sewage sludge on microbial biomass, basal respiration, metabolic quotient and soil enzymatic activity. Appl Soil Ecol 30:65-77

Field A (2009) Discovering statistics using SPSS, 3rd edn. Sage Publications, London

Forsberg LS, Ledin S (2006) Effects of sewage sludge on pH and plant availability of metals in oxidising sulphide mine tailings. Sci Total Environ 358:21-35

Fytili D, Zabanitou A (2008) Utilization of sewage sludge in EU application of old and new methods-a review. Renew Sustain Energy Rev 12:116-140

Garcia-Gil JC, Plaza C, Soler-Rovira P, Polo A (2000) Long-term effects of municipal solid waste compost application on soil enzyme activities and microbial biomass. Soil Biol Biochem 32:1907-1913

Gianfreda L, Rao MA, Piotrowska A, Palumbo G, Colombo C (2005) Soil enzyme activities as affected by anthropogenic alterations: intensive agricultural practices and organic pollution. Sci Total Environ 341:265-279

Grant CD, Campbell CJ, Charnock NR (2002) Selection of species suitable for derelict mine site rehabilitation in New South Wales, Australia. Water Air Soil Pollut 139:215-235

Gülser F, Erdoğan E (2008) The effects of heavy metal pollution on enzyme activities and basal soil respiration of roadside soils. Environ Monit Assess 145:127-133

Hagmann DF, Goodey MN, Mathieu C, Evans J, Aronsonc MFJ, Gallagher F, Krumins JA (2015) Effect of metal contamination on microbial enzymatic activity in soil. Soil Biol Biochem 91:291-297

Hodson ME, Donner E (2013) Managing adverse soil chemical environments. In: Gregory PJ, Nortcliff S (eds) Soil conditions and plant growth, 11th edn. John Wiley and Sons, UK, pp 195-237

Hu Y, Nan Z, Su J, Wang N (2013a) Heavy metal accumulation by poplar in calcareous soil with various degrees of multi-metal contamination: implications for phytoextraction and phytostabilization. Environ Sci Pollut Res 20:7194-9203

Hu B, Liang D, Liu J, Xie J (2013b) Ecotoxicological effects of copper and selenium combined pollution on soil enzyme activities in planted and unplanted soils. Environ Toxicol Chem 32(5):1109-1116

Hua L, Wu W, Liu Y, Chen Y, McBride M (2008) Effect of composting on polycyclic aromatic hydrocarbons removal in sewage sludge. Water Air Soil Pollut 193:259-267

International Organisation for Standards (ISO) (ISO/FDIS 17512-1) (2007) Soil quality-Avoidance test for testing the quality of soils and effects of chemicals on behaviour-part1: test with earthworms (Eisenia fetida and Eisenia andrei). International Organization for Standardization, Genève, Switzerland.

Jiemin C, Wong MH (2013) Effect of earthworm (Pheretima sp.) density on revegetation of lead/zinc metal mine tailings amended with soil. Chin J Popul Resour Environ 6(2):43-48

Jin Z, Li Z, Li Q, Hu Q, Yang R, Tang H, Li M, Huang B, Zhang J, Li G (2014) Canonical correspondence analysis of soil heavy metal pollution, microflora and enzyme activities in the $\mathrm{Pb}-\mathrm{Zn}$ mine tailing dam collapse area of Sidi village, SW China. Environ Earth Sci. doi:10.1007/s12665-014-3421-4

Jones JB (2012) Plant nutrition and soil fertility manual, 2nd edn. Taylor and Francis Group, Boca Raton

Kandeler E, Gerber H (1988) Short-term assay of soil urease activity using colorimetric determination of ammonium. Biol Fertil Soils $6: 68-72$
Karaca A, Naseby DC, Lynch JM (2002) Effect of cadmium contamination with sewage sludge and phosphate fertiliser amendments on soil enzyme activities, microbial structure and available cadmium. Biol Fertil Soils 35:428-434

Khan AG (2002) The significance of microbes. In: Wong MH, Bradshaw AD (eds) The restoration and management of derelict land-morden approaches. World Scientific Publishing Co, New Jersey, pp 80-92

Kızılkaya R, Bayraklı B (2005) Effects of N-enriched sewage sludge on soil enzyme activities. Appl Soil Ecol 30:192-202

Kizilkaya R, Karaca A, Turgay OC, Cetin SC (2011) Earthworm interactions with soil enzymes. In: Karaca A (ed) Biology of earthworms. Springer, London, pp 141-158

Koo N, Lee S, Kim J (2012) Arsenic mobility in the amended mine tailings and its impact on soil enzyme activity. Environ Geochem Health 34:337-348

Lai KM, Ye DY, Wong JWC (1999) Enzyme activities in a sandy soil amended with sewage sludge and coal fly ash. Water Air Soil Pollut 113:261-272

Li J, Zhou X, Yan J, Li H, He J (2015) Effects of regenerating vegetation on soil enzyme activity and microbial structure in reclaimed soils on a surface coal mine site. Appl Soil Ecol 87:56-62

Luczkiewicz A (2006) Soil and groundwater contamination as a result of sewage sludge land application. Pol J Environ Stud 15(6):869-876

Maboeta MS, Classens S, van Rensburg L, van Rensburg PJ (2006) The effects of platinum mining on the environment from a soil microbial perspective. Water Air Soil Pollut 175:149-161

Madejón E, Burgos P, López R, Cabrera F (2001) Soil enzymatic response to addition of heavy metals with organic residues. Biol Fertil Soils 34:144-150

Maiti SK, Saxena NC (1998) Biological reclamation of coalmine spoils without topsoil: an amendment study with domestic raw sewage and grass-legume mixture. Int J Surf Min Reclam Environ 12(2):87-90

Manzano R, Esteban E, Peñalosa JM, Alvarenga P (2014) Amendment application in a multi-contaminated mine soil: effects on soil enzymatic activities and ecotoxicological characteristics. Environ Sci Pollut Res 21:4539-4550

McCulloch J (2003) Asbestos mining and occupational disease in Southern Rhodesia/Zimbabwe, 1915-98. Hist Workshop J $56: 131-152$

McLoughlin PF, Mehra R (1988) Swaziland's macro-economic development environment. J Mod Afr Stud 26(4):661-675

Meeinkuirt W, Pokethitiyook P, Kruatrachue M, Tanhan P, Chaiyarat R (2012) Phytostabilization of Pb-contaminated mine tailings by various tree species in a pot and field trial experiments. Int $\mathrm{J}$ Phytorem 14:925-938

Mertens J, Smolders E (2013) Zinc. In: Alloway BJ (ed) Heavy metals in soils: trace metals and metalloids in soils and their bioavailability, 3rd edn. Springer, London, pp 465-496

Moreno B, Vivas A, Nogales R, Macci C, Masciandaro G, Benitez E (2009) Restoring biochemical activity and bacterial diversity in a trichloroethylene-contaminated soil: the reclamation effect of vermicomposted olive wastes. Environ Sci Pollut Res $16: 253-264$

Nelson DW, Sommers LE (1982) Total carbon, organic carbon and organic matter. In: Page AL, Miller HR, Keeney DR (eds) Methods of soil analysis, part 2: chemical and microbiological properties, 2nd edn. American Society of Agronomy, Wisconsin, pp 539-594

Nicolas C, Kennedy JN, Hernandez T, Garcia C, Six J (2014) Soil aggregation in a semi-arid soil amended with composted and non-composted sewage sludge-a field experiment. Geoderma 219-220:24-31 
Novo LAB, Covelo EF, González L (2013) Phytoremediation of amended copper mine tailings with Brassica juncea. Int J Min Reclam Environ 27(3):215-226

Ogleni N, Ozdemir S (2010) Pathogen reduction effects of solar drying and soil application in sewage sludge. Turk J Agric For 34:509-515

Oorts K (2012) Copper. In: Alloway BJ (ed) Heavy metals in soilstrace metals and metalloids in soils and their bioavailability, 3rd edn. Springer, London, pp 367-394

Pan J, Yu L (2011) Effects of Cd and/or Pb on soil enzyme activities and microbial community structure. Ecol Eng 37:1889-1894

Perez-de-Mora A, Ortega-Calvo JJ, Cabrera F, Madejon E (2005) Changes in enzyme activities and microbial biomass after "in situ" remediation of a heavy metal-contaminated soil. Appl Soil Ecol 28:125-137

Perez-de-Mora A, Burgos P, Cabrera F, Madejon E (2007) In situ amendment and revegetation reduce trace element leaching in a contaminated soil. Water Air Soil Pollut 185:209-222

Qu J, Guangming R, Chen B, Fan J, Yong E (2011) Effects of lead and zinc mining contamination on bacterial community diversity and enzyme activities of vicinal cropland. Environ Monit Assess 182:597-606

Rao MA, Scelza R, Acevedo F, Diez MC, Gianfreda L (2014) Enzymes as useful tools for environmental purposes. Chemosphere 107:145-162

Rate AW, Lee KM, French PA (2004) Application of biosolids in mineral sands mine rehabilitation: use of stockpiled topsoil decreases trace element uptake by plants. Bioresour Technol 91:223-231

Romero E, Benitez E, Nogales R (2005) Suitability of wastes from olive-oil industry for initial reclamation of a $\mathrm{Pb} / \mathrm{Zn}$ mine tailing. Water Air Soil Pollut 165:153-165

Ruiz E, Rodríguez L, Alonso-Azcárate J (2009) Effects of earthworms on metal uptake of heavy metals from polluted mine soils by different crop plants. Chemosphere 75:1035-1041

Santibáñez C, Verdugo C, Ginocchio R (2008) Phytostabilization of copper mine tailings with biosolids: implications for metal uptake and productivity of Lolium perenne. Sci Total Environ 395:1-10

Sastre I, Vicente MA, Lobo MC (1996) Influence of the application of sewage sludges on soil microbial activity. Bioresour Technol 57:19-23

Seleiman MF, Santanen A, Stoddard FL, Makela P (2012) Feedstock quality and growth of bioenergy crops fertilized with sewage sludge. Chemosphere 89:1211-1217

Sneesby GW (1968) Economic development in Swaziland. Geography 53(2):186-189

Soil Science Society of South Africa (1990) Handbook of standard soil testing methods for advisory purposes. Soil Sci Soc S Afr, Pretoria

Speir TW (2008) Relationship between biochemical activity and metal concentration in soil amended with sewage sludge. Dev Soil Sci 32:261-271

Stuben D, Berner Z, Kappes B, Puchelt H (2001) Environmental monitoring of heavy metals and arsenic from $\mathrm{Ag}-\mathrm{Pb}-\mathrm{Zn}$ mining. A case study over two millennia. Environ Monit Assess 70:181-200

Swaziland: Swaziland Environmental Authority (2011) Ngwenya environmental impact assessment and comprehensive mitigation plan. Government Printer, Mbabane

Sydnor ME, Redente EF (2002) Ecosystem restoration reclamation of high-elevation, acidic mine waste with organic amendments and topsoil. J Environ Qual 31:1528-1537
Tabatabai MA (1994) Soil enzymes. In: Weaver RW, Angle S, Bottomley P, Bezdicek D, Smith S, Tabatabai A, Wollum A (eds) Methods of soil analyses-part two: microbiological and biochemical properties. Soil Science Society of America, Madison, pp 775-833

Terrason D, Ojeda G, Ortiz O, Alcaniz JM (2010) Effects of different types of sludge on soil microbial properties: a field experiment on degraded Mediterranean soils. Pedosphere 20(6):681-691

Tordoff GM, Baker AJ, Willis AJ (2000) Current approaches to the revegetation and reclamation of metalliferous mine wastes. Chemosphere 41:219-228

Verdugo C, Sanchez P, Santibanez C, Urrestarazu P, Bustamante E, Silva Y, Gourdon D, Ginocchio R (2011) Efficacy of lime, biosolids, and mycorrhizal for the phytostabilization of sulfidic copper tailings in Chile: A greenhouse experiment. Int $\mathrm{J}$ Phytorem 13:107-125

Waitzenegger J, Collings F, Carstens RO (1970) The Economy of Swaziland (L'économie du Swaziland) (La economía de Swazilandia). Staff Pap Int Monet Fund 17(2):390-452

Wang J, Lu Y, Ding H, Shen G (2007) Effect of cadmium alone and in combination with butachlor on soil enzymes. Environ Geochem Health 29:395-403

Waterhouse BR, Boyer S, Adair KL, Wratten SD (2014) Using municipal biosolids in ecological restoration: what is good for plants and soil may not be good for endemic earthworms. Ecol Eng 70:414-421

Wen B, Hu X, Liu Y, Wang W, Feng M, Shan X (2004) The role of earthworms (Eisenia fetida) in influencing bioavailability of heavy metals in soils. Biol Fertil Soils 40:181-187

Wilke BM (2010) Determination of chemical and physical soil properties. In: Margesin R, Schinner F (eds) Manual of soil analysis: monitoring and assessing soil bioremediation, Soil Biology, vol 5, Springer-Verlag, Berlin, Heidelberg, pp 47-95

Wolff AP, da Costa GM, Dutra F (2011) A comparative study of ultra-fine iron ore tailings from Brazil. Miner Process Extract Metall Rev Int J 32:47-59

Wong MH (2003) Ecological restoration of mine degraded soils, with emphasis on metal contaminated soils. Chemosphere 50:775-780

Wong JWC, Lai KM, Fang M, Ma KK (1998) Effect of sewage sludge amendment on soil microbial activity and nutrient mineralization. Environ Int 24(8):935-943

Yan D, Zhao F, Sun OJ (2013) Assessment of vegetation establishment on tailings dam at an iron ore mining site of suburban Beijing, China, 7 years after reclamation with contrasting site treatment methods. Environ Manage 52:748-757

Zhan J, Sun Q (2014) Development of microbial properties and enzyme activities in copper mine wasteland during natural restoration. Catena 116:86-94

Zhang W, Yao D, Zhang Z, Yang Q, Zhao K, An S (2013) Characteristics of soil enzymes and the dominant species of repair trees in the reclamation of coal mine area. J Coal Sci Eng 19:256-261

Zhao Z, Shahrour I, Bai Z, Fan W, Feng L, Li H (2013) Soils development in opencast coal mine spoils reclaimed for 1-13 years in the West-Northern Loess Plateau of China. European Journal of Soil Biology 55:40-46

Zodrow JJ (1999) Recent applications of phytoremediation technologies. Remed J 9:29-36 